\title{
Molecular Analysis of PROPI, PITI, HESXI, LHX3, and LHX4 Shows High Frequency of PROPI Mutations in Patients with Familial Forms of Combined Pituitary Hormone Deficiency
}

\begin{abstract}
Combined Pituitary Hormone Deficiency (CPHD) is a prevalent disease in Neuroendocrinology services. The genetic form of CPHD may originate from mutations in pituitary transcription factor (PTF) genes and the pituitary image in these cases may give a clue of what PTF is most probably mutated: defects in $L H X 4$ are usually associated with ectopic posterior pituitary (EPP); defects in $L H X 3, P I T 1$, and PROP1, with normally placed posterior pituitary (NPPP); HESX1 mutations are associated with both. Objective: To identify mutations in PTF genes in patients with idiopathic hypopituitarism followed in our service, based on the presence or absence of EPP on sellar MRI. Methods: Forty patients with idiopathic hypopituitarism (36 families, 9 consanguineous), followed in the Neuroendocrinology Outpatient Clinic of UNIFESP, Brazil, were submitted to sequencing analyses of PTF genes as follows: $L H X 3, H E S X 1, P I T 1$, and PROP1 were sequenced in patients with NPPP (26/40) and HESX1 and LHX4 in patients with EPP (14/40). Results: We identified only PROP1 mutations in 9 out of 26 patients with CPHD and NPPP (35\%). Since eight of them came from 4 consanguineous families, the prevalence of PROP1 mutations was higher when only consanguineous families were considered $(44 \%, 4 / 9)$. At the end of the study, we decided to sequence PROP1 in patients with EPP, just to confirm that they were not candidates for PROP1 mutations. No patients with EPP had PROP1 or other PTF mutations. Conclusions: Patients with idiopathic CPHD and NPPP, born from consanguineous parents, are the strong candidates for PROP1 mutations. Other developmental gene(s) may be involved in the genesis of idiopathic hypopituitarism associated with EPP. (Arq Bras Endocrinol Metab 2007;51/7:1097-1103)
\end{abstract}

Keywords: Pituitary transcription factor; PROP1; Hypopituitarism; Combined pituitary hormone deficiency

\section{RESUMO}

Análise Molecular de PROP1, PIT1, HESX1, LHX3 e LHX4 Mostra Alta Frequiência de Mutações no PROP1 em Pacientes com Formas Familiares de Deficiência Combinada de Hormônios Hipofisários.

Deficiência Combinada de Hormônios Hipofisários (DCHH) é uma doença prevalente em todos os serviços de Neuroendocrinologia. A DCHH de origem genética pode resultar de mutações nos genes de fatores de transcrição hipofisários (FTH), e a ressonância magnética (RM) de sela desses pacientes pode indicar qual FTH tem maior probabilidade de estar mutado: mutações no $L H X 4$ estão geralmente associadas a neuro-hipófise ectópica (NHE); mutações no LHX3, PIT1 e PROP1, a neuro-hipófise tópica (NHT); mutações no HESX1 podem estar associadas a NHE e NHT. Objetivo: Identificar mutações nos FTH em pacientes acompanhados em nosso serviço, portadores de hipopituitarismo idiopático, selecionando os genes a serem estudados de acordo com a presença ou ausência de NHE à RM sela. Métodos: Os genes dos FTH foram seqüenciados em 40 pacientes com hipopituitarismo idiopático (36 famílias, 9 consangüíneas), acompanhados na unidade de Neuroendocrinologia da UNIFESP, SP, Brasil: LHX3, HESX1, PIT1 e PROP1 foram seqüenciados nos pacientes com NHT (26/40) e HESX1 e LHX4, nos pacientes com NHE (14/40). Resultados: Somente mutações PROP1 foram identificadas em 9 de 26 pacientes (35\%) com NHT, 8 deles provenientes de 4 famílias consangüíneas $(4 / 9,44 \%)$. Uma vez que mutações no $P R O P 1$ foram tão freqüentes, decidimos, ao final do estudo, seqüenciá-lo também nos pacientes com NHE. Nenhum paciente com NHE apresentou mutações no PROP1 ou em outro FTH. Conclusão: Mutações no gene PROP1 foram encontradas em 22,5\% (9/40) de todos os pacientes, em 35\% (9/26) dos pacientes com NHT e em 44\% (4/9) se considerarmos somente as famílias consangüíneas. Portanto, pacientes com DCHH idiopática e NHT, provenientes de famílias de pais consangüíneos, são os melhores candidatos a mutações PROP1. (Arq Bras Endocrinol Metab 2007;51/7:1097-1103)

Descritores: Fator de transcrição hipofisário; PROP1; Hipopituitarismo; Deficiência combinada de hormônios hipofisários

\section{artigo original}

\author{
TERESA C. VIEIRA \\ VALTER T. BOLDARINE \\ JULIO ABUCHAM
}

Division of Endocrinology,

Department of Medicine,

Universidade Federal de São

Paulo - UNIFESP, São Paulo, SP. 
C ombined Pituitary Hormone Deficiency (CPHD) includes a heterogeneous group of disorders characterized by impaired production of growth hormone $(\mathrm{GH})$ and one or more of the other anterior pituitary hormones, and it is a prevalent disease in all Neuroendocrinology services. Clinically, CPHD is characterized by a combination of the following findings: short stature, hypothyroidism, impaired sexual development and hypocortisolism. CPHD may result from acquired lesions in the hypothalamic-pituitary region (tumor, trauma, surgery, irradiation), from genetically defined conditions, or may be idiopathic. CPHD from genetic cause has an incidence of approximately $1: 8,000$ births and is usually sporadic, but nearly $5-30 \%$ of cases are familial (1-3).

During pituitary embryogenesis, homeobox genes (HESX1, PITX1 and 2, LHX3, LHX4, SIX6, PROP1, PIT1, TPIT, and SOX3) become activated in the region of the future anterior pituitary gland, following a specific temporal and spatial pattern of activation. They encode pituitary transcription factors (PTF), which are nuclear proteins that bind to regulatory DNA sequences of target genes, activating or inhibiting their transcription. The PTF are involved in the development of the anterior pituitary gland, from the thickening and invagination of the roof of the primitive oral cavity, to the terminal differentiation of the five different pituitary cell types (somatotrophs, lactotrophs, thyrotrophs, gonadotrophs, and corticothophs) (4). PTF may be pituitary-specific (PITl, PROP1, TPIT) or pituitary non-specific (HESXI, PITX1 and 2, LHX3, LHX4, SIX6, SOX3). The latter are also expressed in other regions such as the anterior central nervous system (HESXI, SOX3), the eyes (PITX2, SIX6), the teeth, the heart (PITX2), the cervical spine (LHX3), the cerebellum (LHX4), and the spinal cord (SOX3) $(5,6)$.

Mutations in HESX1, LHX3, LHX4, PROP1, PITl genes lead to the genetic form of CPHD. Clinically, the patients may present two or more deficiencies of the anterior pituitary hormones. At times, the hypopituitarism may present as an isolated anterior pituitary hormone deficiency (usually GH deficiency), which gradually evolves to CPHD $(5,7,8)$. HESXI mutations cause either isolated $\mathrm{GH}$ deficiency or CPHD, associated or not with other anomalies such as septo-optic dysplasia and agenesis of the corpus callosum $(5,9,10)$; LHX3 mutations lead to $\mathrm{GH}$, TSH, PRL, and gonadotrophin deficiencies, associated with short cervical spine and limited neck rotation (11-14); LHX4 mutations cause GH, TSH, and ACTH deficiencies and cerebellar abnormalities (15). Defects in
PITI gene cause GH, TSH, and PRL deficiencies, and in PROPI cause deficiencies in pituitary hormones produced by PITI dependent cell lineages (somatotrophs, thyrotrophs, lactotrophs), as well as evolving gonadotrophin and corticotrophin deficiencies $(3,8,16-19)$.

The sellar magnetic resonance image (MRI) findings in patients with PTF mutations are variable and may give a clue of what PTF is most probably mutated: $L H X 4$ mutations are usually associated with an EPP, whereas PIT1, PROPI, and LHX3 mutations are associated with NPPP. HESXI mutations may be associated with EPP or NPPP $(5,20-22)$. With regard to the image of the anterior pituitary, the majority of the patients with PTF mutations have a hypoplastic or normal anterior pituitary gland, but an enlarged pituitary mass resembling hyperplasia of the adenohypophysis may be detected less frequently in some patients with PROPI mutations.

In this study, we searched for mutations in HESX1, LHX3, LHX4, PITI, and PROPl genes in a cohort of patients with idiopathic hypopituitarism who are followed in our neuroendocrine service. The objective of this search was to identify the prevalence of PTF gene mutations in our patients and to correlate the mutations identified with the different CPHD phenotypes, improving our understanding about some genetically identified cases of CPHD.

\section{PATIENTS AND METHODS}

\section{Patients}

Patients with idiopathic hypopituitarism who are followed in the Neuroendocrinology Outpatient Clinic of the Universidade Federal de São Paulo (UNIFESP), in São Paulo, Brazil, were recruited into the study. After obtaining approval for the study protocol by the Institutional Ethics Committee, informed written consent was obtained from the patients who agreed to participate of the study.

Forty patients (30 males, 10 females) with a mean age at the diagnosis of hypopituitarism of 11.4 years (range $0.5-37 \mathrm{yr}$ ) participated in the study. Thirteen patients were born from consanguineous marriages ( 9 consanguineous families) and all patients had GH deficiency. The different pituitary hormonal deficiency profiles, the imaging findings and the characteristics of the patients are listed in tables 1 and 2. The patients were divided in two groups: Group 1idiopathic hypopituitarism and ectopic posterior pituitary (EPP): 14 patients ( 10 males : 4 females). All patients from this group had initially HESXI and LHX4 genes sequenced. However, since PROPI mutations were so common, we decided to sequence PROPI in these patients later on in the study. Group 2- idiopathic hypopituitarism and normally 
Table 1. Clinical, hormonal and radiological features of the 14 patients with ectopic posterior pituitary.

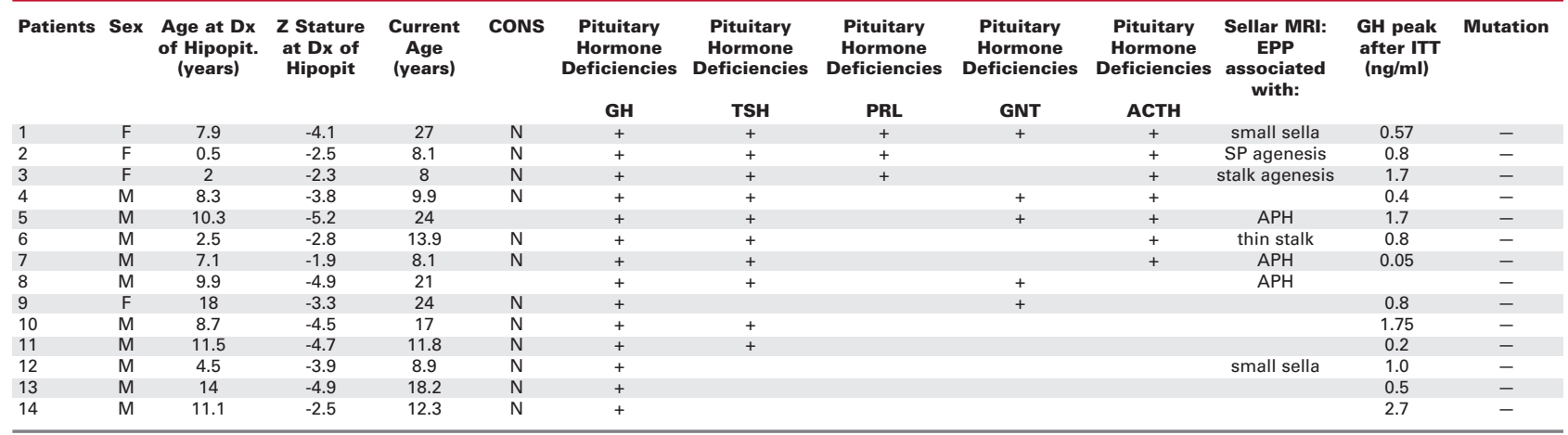

Cons = consanguinity, $\mathrm{N}=\mathrm{No}, \mathrm{EPP}=$ Ectopic posterior pituitary, $\mathrm{SP}=$ septum pellucidum, $\mathrm{APH}=$ anterior pituitary hypoplasia.

Table 2. Clinical, hormonal, and radiological features of the 26 patients with normally placed posterior pituitary.

\begin{tabular}{|c|c|c|c|c|c|c|c|c|c|c|c|c|c|}
\hline Patients & Sex & $\begin{array}{c}\text { Age at Dx } \\
\text { of Hipopit. } \\
\text { (years) }\end{array}$ & $\begin{array}{c}\text { Z Stature } \\
\text { at Dx of } \\
\text { Hipopit }\end{array}$ & $\begin{array}{c}\text { Current } \\
\text { Age } \\
\text { (years) }\end{array}$ & cons & $\begin{array}{c}\text { Pituitary } \\
\text { Hormone } \\
\text { Deficiencies } \\
\text { GH }\end{array}$ & $\begin{array}{c}\text { Pituitary } \\
\text { Hormone } \\
\text { Deficiencies } \\
\text { TSH }\end{array}$ & $\begin{array}{c}\text { Pituitary } \\
\text { Hormone } \\
\text { Deficiencies } \\
\text { PRL }\end{array}$ & $\begin{array}{c}\text { Pituitary } \\
\text { Hormone } \\
\text { Deficiencies } \\
\text { GNT }\end{array}$ & $\begin{array}{c}\text { Pituitary } \\
\text { Hormone } \\
\text { Deficiencies } \\
\text { ACTH }\end{array}$ & $\begin{array}{c}\text { Sellar } \\
\text { MRI }\end{array}$ & $\begin{array}{c}\text { GH peak } \\
\text { after ITT } \\
\text { (ng/ml) }\end{array}$ & Mutation \\
\hline $\begin{array}{l}15^{*} \\
\text { (family I) }\end{array}$ & $\mathrm{F}$ & 11 & -6.0 & 24 & $Y$ & + & + & + & + & + & Normal pit. & 1.2 & $\begin{array}{c}\text { PROP1 } \\
\text { 301302delAG }\end{array}$ \\
\hline $\begin{array}{l}16^{*} \\
\text { (family I) }\end{array}$ & $\mathrm{F}$ & 10 & -4.9 & 22 & Y & + & + & + & + & + & Norma pit. & 0.2 & $\begin{array}{c}\text { PROP1 } \\
\text { 301302delAG }\end{array}$ \\
\hline $\begin{array}{l}17 \\
\text { (family II) }\end{array}$ & $M$ & 5 & -4.2 & 8 & $Y$ & + & + & + & & + & Nomal pit. & 0.9 & $\begin{array}{c}\text { PROP1 } \\
\text { 301302delAG) }\end{array}$ \\
\hline $\begin{array}{l}18 \\
\text { (family II) }\end{array}$ & M & 8 & -4.9 & 11 & Y & + & + & + & & + & Normal pit. & 0.4 & $\begin{array}{c}\text { PROP1 } \\
\text { (301302delAG }\end{array}$ \\
\hline $\begin{array}{l}19 * \\
\text { (family III) }\end{array}$ & $\mathrm{F}$ & 10 & -6.0 & 24 & N & + & + & + & + & + & $\mathrm{APH}$ & $<0.5$ & $\begin{array}{c}\text { PROP1 } \\
\text { 301302delAG }\end{array}$ \\
\hline $\begin{array}{l}20^{*} \\
\text { (family IV) }\end{array}$ & $\mathrm{F}$ & 15 & -2.6 & 26 & Y & + & + & + & + & & $\mathrm{APH}$ & 0.2 & $\begin{array}{l}\text { PROP1 } \\
\text { R99Q }\end{array}$ \\
\hline $\begin{array}{l}21^{*} \\
\text { (family IV) }\end{array}$ & $M$ & 17 & -4.0 & 25 & Y & + & + & + & + & & APH & 0.45 & $\begin{array}{l}\text { PROP1 } \\
\text { R990 }\end{array}$ \\
\hline $\begin{array}{l}22^{*} \\
\text { (family V) }\end{array}$ & $\mathrm{M}$ & 29 & -1.0 & 41 & Y & + & + & + & + & + & $\mathrm{APH}$ & 1.4 & $\begin{array}{l}\text { PROP1 } \\
\text { R120C }\end{array}$ \\
\hline $\begin{array}{l}23^{*} \\
\text { (family V) }\end{array}$ & M & 37 & -3.4 & 39 & $Y$ & + & + & + & + & + & APH & $\begin{array}{c}\text { IGFI: } \\
21 \mathrm{ng} / \mathrm{mL}\end{array}$ & $\begin{array}{l}\text { PROP1 } \\
\text { R120C }\end{array}$ \\
\hline 24 & $M$ & 8.2 & -3.9 & 25 & N & + & + & + & + & + & $\mathrm{APH}$ & 1.1 & - \\
\hline 25 & $\mathrm{M}$ & 12.9 & -5.8 & 29 & $\mathrm{~N}$ & + & + & + & + & + & APH & 0.27 & - \\
\hline 26 & $\mathrm{~F}$ & 19 & n.a. & 22 & Y & + & + & + & + & & APH & 0.05 & - \\
\hline 27 & M & 14 & -5.1 & 31 & $\mathrm{~N}$ & + & + & & + & + & APH & 3.1 & - \\
\hline 28 & M & 12.5 & -4.4 & 23 & $Y$ & + & + & & + & + & APH & n.a. & - \\
\hline 29 & $\mathrm{M}$ & 12.8 & -4.3 & 26 & $\mathrm{~N}$ & + & + & + & & & APH & 2.4 & - \\
\hline 30 & M & 8.6 & -4.1 & 20 & $\mathrm{~N}$ & + & + & + & & & $\mathrm{APH}$ & n.a. & - \\
\hline 31 & M & 17 & -8.38 & 22 & Y & + & + & & + & & APH & 0.7 & - \\
\hline 32 & M & 4 & -2.9 & 7 & Y & + & + & & & & $\begin{array}{c}\text { C.C. } \\
\text { Agenesis }\end{array}$ & 3.2 & - \\
\hline 33 & $M$ & 3.8 & -4.4 & 21 & N & + & + & & & & $\begin{array}{l}\text { Pit Stalk } \\
\text { Agenesis }\end{array}$ & 3.0 & - \\
\hline 34 & M & 15 & -3.9 & 20 & $\mathrm{~N}$ & + & + & & + & & APH; CIL & 1.7 & - \\
\hline 35 & $\mathrm{~F}$ & 6.1 & -3.2 & 8 & Y & + & + & & & & $\mathrm{APH}$ & 0.6 & - \\
\hline 36 & M & 13 & -4.7 & 25 & $\mathrm{~N}$ & + & + & & + & & APH & 2.9 & - \\
\hline 37 & M & 9 & -5.2 & 12 & $\mathrm{~N}$ & + & & & & & $\mathrm{APH}$ & $\begin{array}{l}0.8 \\
\mathrm{P} 58 \mathrm{P}\end{array}$ & $\begin{array}{c}\text { PROP1 } \\
\text { polymorphism }\end{array}$ \\
\hline 38 & $M$ & 11 & -3.2 & 13 & N & + & & & & & $\mathrm{APH}$ & 0.2 & - \\
\hline 39 & M & 6.8 & -3.9 & 11 & $\mathrm{~N}$ & + & & & & & APH & 0.1 & - \\
\hline 40 & M & 7.5 & -3.7 & 12 & $\mathrm{~N}$ & + & & & & & $\begin{array}{l}\text { Normal } \\
\text { pit. }\end{array}$ & 0.6 & - \\
\hline
\end{tabular}

* families reported before, Cons = consanguinity, $\mathrm{Y}=\mathrm{Yes}, \mathrm{N}=\mathrm{No}, \mathrm{APH}=$ anterior pituitary hypoplasia, C.C. = Corpus Calosum, $\mathrm{CIL}=$ cyst intermidiate lobe, n.a. $=$ not available. 
placed posterior pituitary (NPPP): 26 patients (20 males : 6 females). All the patients of this group had HESX1, LHX3, PROPI, and PITI genes sequenced, but only the patients with GH, TSH, and PRL or GH and TSH deficiencies had the PITl gene sequenced ( 5 patients).

\section{Clinical, hormonal and radiological evaluation}

Clinical data from some of the patients were obtained retrospectively from the patients' records and included history of consanguinity, family history, auxological data, parental heights and anterior pituitary hormone evaluation. Other patients were included in the study as soon as the diagnosis of hypopituitarism was made. To assess anterior pituitary function, hormone levels were measured at baseline (TSH, free T4, PRL, LH, FSH, IGF-I, cortisol, estradiol/testosterone) and a combined pituitary stimulation test was performed when necessary. For the combined test, glucose, $\mathrm{GH}$, cortisol, TSH, PRL, LH, and FSH were measured before and at 15, 30, 45 and 60 min after iv administration of $0.1 \mathrm{U} / \mathrm{kg}$ insulin, $200 \mu \mathrm{g} \mathrm{TRH}$, and $100 \mu \mathrm{g} \mathrm{GnRH}$.

The following were the diagnostic methods used for hormonal measurements: i) Free T4, TSH, PRL, GH, LH, and FSH: flurometric assay (Delfia, Wallac Oy, Turku, Finland); ii) cortisol: RIA (Diagnostic Products, Los Angeles, CA, USA); iii) IGF-I: Immunoflorimetric assay after ethanol extraction using specific monoclonal antibodies (DSL kit).

The criteria used for the diagnosis of GH deficiency were auxological, hormonal, and radiological: poor growth velocity (more than I SD below the mean for age), IGF-I low for age, abnormal GH peak response $(<3 \mathrm{ng} / \mathrm{ml})$ to hypoglycemia on Insulin Tolerance Test (ITT) and anatomic pituitary abnormalities on MRI. Some patients with abnormal sellar MRIs had only one GH stimulation test performed (ITT). All patients with normal sellar MRIs were submitted to a second GH stimulation test with clonidine. Not all patients had IGF-I measured.

Radiological studies of the sella turcica were performed in a Philips Gyroscan ACS-NT 1,5 tesla. The coronal images were obtained using $2-\mathrm{mm}$ slices. The maximal height of the pituitary was measured perpendicularly to the sella turcica. The classification of the size of the anterior pituitary (normal, small or increased) was made accordingly to the normal controls from the studies of Tsunoda and Argyroupoulous (9,30).

\section{Genomic analysis}

DNA was extracted from peripheral lymphocytes of the patients using a Quiagen Midi Kit (Quiagen), following the manufacturer's protocol.

All coding exons of HESX1, LHX3, LHX4, PITI, PROPI genes were amplified by Polymerase Chain Reaction (PCR). One hundred nanograms of human genomic DNA were used as template in a $100 \mathrm{uL}$ PCR mixture containing $20 \mathrm{mM}$ Tris- $\mathrm{HCl}$ ( $\mathrm{pH} 8.4$ ), $50 \mathrm{mM} \mathrm{KCl}, 1.5 \mathrm{mM} \mathrm{MgCl}$, $0.2 \mathrm{mM}$ deoxy-NTPs, $2.5 \mathrm{U}$ Taq polymerase (PCR Reagent System, Life-Technologies) and $0.1 \mathrm{nM}$ of upstream and downstream specific primers. The sequence of the PCR primers and the PCR thermal cycling program have been described elsewhere $(9,14,15,19,31)$. PCR products were analyzed in $1.8 \%$ agarose gel and purified using a PCR Product Purification Kit (Life Technologies, USA). Direct sequencing of the PCR products was carried out in both directions, using the ABI Prism Big Dye terminator cycle sequencing ready reaction version 3.0 (Applied Biosystems) in an ABI Prism 3100 DNA Sequencer (Perkin Elmer Corporation).

\section{RESULTS}

\section{Genomic sequencing of the homeobox genes}

Three different PROPI homozygous gene mutations [301-302delAG (exon 2), 358C > T (exon 3), and 296G $>$ A (exon2)], were found in 9 patients, all of them with normally placed posterior pituitary (table 2 ). They were four pairs of siblings from 4 families of consanguineous parents, and one patient from a nonconsanguineous family (table 2 ). The 301-302delAG mutation leads to a frame shift and a truncated PROPI protein with null function. The $358 \mathrm{C}>\mathrm{T}$ missense mutation predicts an amino acid change at codon 120 replacing a much conserved arginine by a cysteine (R120C) in the third helix of the DNA-binding domain of the PROPl, and the mutant protein has an eight-fold reduction in DNA binding affinity and impaired trans-activation activity (17). The mutation $296 \mathrm{G}>\mathrm{A}$ predicts an amino acid change at codon 99 replacing a highly conserved arginine by a glutamine (R99Q) in the second helix of the paired DNA-binding homeodomain of PROPl. The mutant protein presents a weak binding to its target DNA sequence but still preserves some functional activity (32).

We also identified in one patient a PROPI heterozygous polymorphism CCG/CCA, in exon 2 of PROPI (nucleotide position 1965). This polymorphism does not change the amino acid in the PROPl protein (P58P) and has been found in normal populations (OMIM SNP rs2233784).

No mutations were found in HESXI, LHX3, LHX4 or PITI genes in all the patients tested. No mutations were found in patients with EPP.

\section{DIscussion}

In the present study, we performed mutational analysis of the HESXI, LHX3,LHX4, PROPI, and PITI genes in a cohort of 40 patients with idiopathic 
hypopituitarism followed in one large neuroendocrinology service of the southeast region of Brazil, the Neuroendocrinology Clinic / Medicine Department of Escola Paulista de Medicina, Universidade Federal de São Paulo. Since LHX4 and HESXI are more likely to be associated with EPP, and $L H X 3$, PITI, PROPI, and HESXI with NPPP (5), we divided the patients in two groups, according to the presence or not of EPP on sellar MRI, and searched the candidate genes in each group.

We identified 3 different PROPI mutations (301-302delAG, R99Q, and Rl20C) in 9 patients, all of them with CPHD and NPPP. The patients with EPP showed no mutations in the genes studied (HESX1, $L H X 4$, and PROPI) and this is compatible with the rarity of PTF mutations found in patients with EPP $(10,15,20,33,34)$. Perhaps other developmental genes yet to be identified may be involved in the etiology of EPP, or another pathogenic mechanism could be responsible for this abnormality $(35,36)$.

The 9 patients who carry PROPI mutations are four pairs of siblings belonging to four independent consanguineous families, and one patient born from non-consanguineous parents. They correspond to $22.5 \%(9 / 40)$ of all patients in this cohort. If we consider only the consanguineous families, $44 \%$ of them (4/9) had members with PROPI mutations. The high prevalence of PROPI mutations in our patients from consanguineous families reinforces previous studies that reported PROPI mutations in 36 to $50 \%$ of all familial cases of CPHD $(3,19,33,37,38)$. On the other hand, the absence of molecular abnormalities in the other PTF genes studied reinforces the scarcity of these mutations and points to the possible involvement of other developmental genes in the pathogenesis of the remaining cases of idiopathic hypopituitarism (1).

The most prevalent PROPI mutation in our cohort was the 301-302delAG in exon 2 , found in 5 patients from 3 families. Two of them have been reported before $(28,39)$. This mutation is so common that it is considered by several authors as a mutational hotspot $(19,25)$. All five patients with the 301-302del AG presented severe short stature and signs of GH and TSH deficiencies before the age of 10 years. All the adult patients bearing this mutation also presented gonadotrophin deficiency. Because this mutation codifies a truncated protein with null function, it leads to a severe CPHD phenotype, affecting all the anterior pituitary hormones. The ACTH deficiency usually occurs in the third decade of life $(17-19,23,25,39)$. In our cohort of patients, the older brother from family II presented a slightly compromised cortisol response to hypoglycemia $(15.4 \mu \mathrm{g} / \mathrm{dl})$ at the age of 11 years, and the patients from families I and III presented ACTH deficiency at the ages of 16 and 17 years (table 3 ). Hypocortisolaemia occurring during the second decade of life is an uncommon finding but has been described before $(37,40)$.

The other two mutations found (R99Q and the R120C) are rarer. The PROPI 358C >T (Rl20C) missense mutation identified in family $\mathrm{V}$ has never been described in Brazilian families, and only a few families of European, Mexican-American, and Jewish-Moroccan origins have been reported before (7,17,41-43). The two brothers, born from a consanguineous marriage, developed progressive $\mathrm{CPHD}$ but were only diagnosed in adulthood (at 29 and 37 years of age). The central hypothyroidism was mild in both cases, GH deficiency was very mild in one case, hypogonadism was equally severe in both cases, and ACTH deficiency appeared at different ages (table 3 ). This illustrates the heterogeneity of this mutation.

The other mutation present in this cohort of patients, R99Q, in family IV, is also responsible for a progressive CPHD phenotype and was reported by our group three years ago. In this family, the younger brother had been diagnosed in childhood with familial short stature and constitutional delay of growth, and only in the second decade of life the diagnosis of $\mathrm{GH}$ deficiency associated with other pituitary deficiencies was established. The same happened with his older sister who looked for medical attention only at the age of 15 years for lack of puberty, while her stature was compatible with her target height and she had no symptoms of other pituitary hormone deficiencies (table 3). The phenotype of these siblings is also compatible with a mild PROPl deficiency (32).

One last remark is the predominance of male patients with CPHD in our cohort (3:1, M:F). Mutations in $S O X 3$, another pituitary transcription factor gene located at Xq26, have recently been described in males with congenital X-linked hypopituitarism. These patients may present mental retardation and/or anatomical abnormalities in the corpus callosum and pituitary $(44,45)$. The molecular study of this gene in our male patients is planned for the near future.

In summary, our cohort of patients shows that PTF gene mutations such as HESX1, LHX3, LHX4, and PITI are rare in patients with idiopathic hypopituitarism. On the other hand, PROPI mutations are common among patients with CPHD and normally placed posterior pituitary that are born from consanguineous parents. Therefore, patients with these features are the strong candidates for PROPI mutations. 
Table 3. Hormonal profile of the patients with PROP1 mutations.

\begin{tabular}{|c|c|c|c|c|c|c|c|c|c|c|}
\hline $\begin{array}{l}\text { Patient / } \\
\text { Mutation }\end{array}$ & Sex & $\begin{array}{c}\text { Age at } \\
\text { diagnosis } \\
\text { (years) }\end{array}$ & $\begin{array}{l}\text { Height } \\
\text { (cm) }\end{array}$ & $\begin{array}{c}\text { FT4 (ng/dl) / } \\
\text { TSH (U/L) }\end{array}$ & $\begin{array}{c}\text { PRL } \\
\text { (ng/ml) }\end{array}$ & $\begin{array}{l}\text { IGF-I } \\
\text { ng/mI }\end{array}$ & $\begin{array}{c}\text { Peak GH } \\
\text { (ng/ml) } \\
\text { after ITT }\end{array}$ & $\begin{array}{c}\text { Cortisol } \\
\text { (ug/dl) } \\
\text { Basal and } \\
\text { Peak (ITT) }\end{array}$ & $\begin{array}{c}\text { LH / FSH } \\
\text { (U/L) } \\
\text { after GnRH }\end{array}$ & $\begin{array}{l}\text { Testo } \\
\text { ng/dl }\end{array}$ \\
\hline $\begin{array}{l}15 \\
\text { (family I) } \\
\text { 301-302delAG }\end{array}$ & $\mathrm{F}$ & 11 & $\begin{array}{c}103.5 \\
(-6.0 \mathrm{SD})\end{array}$ & $0.3 / 1.8$ & 3.9 & - & 1.2 & $\begin{array}{l}P>18(11 y r) \\
\text { B: } 4.5(16 y r)\end{array}$ & $0.2 / 0.2$ & - \\
\hline $\begin{array}{l}16 \\
\text { (family I) } \\
\text { 301-302delAG }\end{array}$ & $\mathrm{F}$ & 10 & $\begin{array}{c}103 \\
(-4.9 \mathrm{SD})\end{array}$ & $0.6 / 2.6$ & 4.5 & - & 0.2 & $\begin{array}{l}P>18(10 y r) \\
B: 2.2(16 y r)\end{array}$ & $0.1 / 0.3$ & - \\
\hline $\begin{array}{l}17 \\
\text { (family II) } \\
\text { 301-302delAG }\end{array}$ & M & 5 & $\begin{array}{c}90 \\
(-4.2 \mathrm{SD})\end{array}$ & $0.6 / 2.0$ & 11.2 & $<6$ & 0.9 & P: 18.3 (8 yrs) & n.d. & n.d. \\
\hline $\begin{array}{l}18 \\
\text { (family II) } \\
\text { 301-302delAG }\end{array}$ & $M$ & 8 & $\begin{array}{c}101 \\
(-4.9 \mathrm{SD})\end{array}$ & $0.7 / 1.1$ & 9.4 & $<6$ & 0.4 & P: 15.4 (11 yrs) & B: $<0.1 / 0.3$ & n.d. \\
\hline $\begin{array}{l}19 \\
\text { (family III) } \\
\text { 301-302delAG }\end{array}$ & $\mathrm{F}$ & 10 & $\begin{array}{c}99 \\
(-6.0 \mathrm{SD})\end{array}$ & TT4*: 3.8/2.8 & 1.2 & 41.3 & $<0.5$ & B: $2.1(17 \mathrm{yr})$ & $<1.5 /<1.5$ & - \\
\hline $\begin{array}{l}20 \\
\text { (family IV) } \\
\text { R990 }\end{array}$ & $\mathrm{F}$ & 15 & $\begin{array}{c}144 \\
(-2.6 \mathrm{SD})\end{array}$ & $0.7 / 1.5$ & 6.9 & 112 & 0.2 & B: $10(10 y r)$ & $1.0 / 5.8$ & - \\
\hline $\begin{array}{l}21 \\
\text { (family IV) } \\
\text { R990 }\end{array}$ & M & 17 & $\begin{array}{l}145.5 \\
(-4.0)\end{array}$ & $0.7 / 1.0$ & 4.9 & 88 & 0.45 & P: 18.1 (17 yr) & $4.8 / 2.0$ & $<30$ \\
\hline $\begin{array}{l}22 \\
\text { (family V) } \\
\text { R120C }\end{array}$ & $M$ & 29 & $\begin{array}{c}170 \\
(-1.0 \mathrm{SD})\end{array}$ & $0.6 / 4.7$ & $<3$ & - & 1.4 & $\mathrm{P}:<0.9(29 \mathrm{yr})$ & $8 / 1$ & 22 \\
\hline $\begin{array}{l}23 \\
\text { (family V) } \\
\text { R120C }\end{array}$ & $M$ & 37 & $\begin{array}{c}154 \\
(-3.4 \mathrm{SD})\end{array}$ & $0.4 / 3.7$ & $<3$ & 21 & - & $\begin{array}{l}\text { B: } 7.7(42 \mathrm{yr}) \\
\text { B: } 2.0(45 \mathrm{yr})\end{array}$ & B: $<2 /<1$ & 8 \\
\hline Normal values & & & & $0.8-2.7$ & 3-15 & ** & $>3$ & $\begin{array}{l}\text { B: } 5-25 \\
P:>18\end{array}$ & $\begin{array}{l}\text { LHB: }<14 \\
\text { LHP: }>4-6 x\end{array}$ & $\begin{array}{c}\text { Pre-pubertal: } \\
<50 \\
\text { adult: } \\
300-950\end{array}$ \\
\hline
\end{tabular}

* TT4 = totalT4 ug/dl (normal values: 4-11 ug/dl), n.d. = not done, B = Basal.

** IGFI normal values: < 6 yr = 20-200 ng/ml, 6-12 yr: 88-450 ng/ml, 13-16 yr: 200-900 ng/ml, 17-24 yr: 180-780 ng/ml, 25-39 yr: 114-400 ng/ml.

\section{ACKNOWLEDGMENTS}

This work was supported by grant \# 04/01162-5 from FAPESP (Fundação de Amparo à Pesquisa do Estado de São Paulo).

\section{REFERENCES}

1. Dattani MT, Robinson IC. The molecular basis for developmental disorders of the pituitary gland in man. Clin Genet 2000;57(5):337-46.

2. Rainbow LA, Rees SA, Shaikh MG, Shaw NJ, Cole T, Barrett TG, et al. Mutation analysis of POUF-1, PROP-1 and HESX-1 show low frequency of mutations in children with sporadic forms of combined pituitary hormone deficiency and septooptic dysplasia. Clin Endocrinol (Oxf) 2005;62(2):163-8.

3. Cogan JD, Wu W, Phillips JA 3rd, Arnhold IJ, Agapito A Fofanova OV, et al. The PROP1 2-base pair deletion is a common cause of combined pituitary hormone deficiency. J Clin Endocrinol Metab 1998;83(9):3346-9.

4. Zhu X, Rosenfeld MG. Transcriptional control of precursor proliferation in the early phases of pituitary development. Curr Opin Genet Dev 2004;14(5):567-74.

5. Dattani MT. Growth hormone deficiency and combined pituitary hormone deficiency: does the genotype matter? Clin Endocrinol (Oxf) 2005;63(2):121-30.
6. Cohen LE, Radovick S. Molecular basis of combined pituitary hormone deficiencies. Endocr Rev 2002;23(4):431-42.

7. Fluck C, Deladoey J, Rutishauser K, Eblé A, Marti U, Wu W, et al. Phenotypic variability in familial combined pituitary hormone deficiency caused by a PROP1 gene mutation resulting in the substitution of Arg $\rightarrow$ Cys at codon 120 (R120C). J Clin Endocrinol Metab 1998;83(10):3727-34.

8. Bottner A, Keller E, Kratzsch J, Stobbe H, Weigel JF, Keller A, et al. PROP1 mutations cause progressive deterioration of anterior pituitary function including adrenal insufficiency: a longitudinal analysis. J Clin Endocrinol Metab 2004;89(10):5256-65.

9. Dattani MT, Martinez-Barbera JP, Thomas PQ, Brickman JM, Gupta R, Martensson IL, et al. Mutations in the homeobox gene HESX1/HESX1 associated with septo-optic dysplasia in human and mouse. Nat Genet 1998;19(2):125-33.

10. Carvalho LR, Woods KS, Mendonca BB, Marcal N, Zamparini AL, Stifani S, et al. A homozygous mutation in HESX1 is associated with evolving hypopituitarism due to impaired repressorcorepressor interaction. J Clin Invest 2003;112(8):1192-201.

11. Netchine I, Sobrier ML, Krude H, Schnabel D, Maghnie M, Marcos $\mathrm{E}$, et al. Mutations in $L H X 3$ result in a new syndrome revealed by combined pituitary hormone deficiency. Nat Genet 2000;25(2):182-6.

12. Sloop KW, Walvoord EC, Showalter AD, Pescovitz $\mathrm{OH}$, Rhodes SJ. Molecular analysis of LHX3 and PROP-1 in pituitary hormone deficiency patients with posterior pituitary ectopia. J Clin Endocrinol Metab 2000;85(8):2701-8.

13. Bhangoo AP, Hunter CS, Savage JJ, Anhalt H, Pavlakis S, Walvoord EC, et al. Clinical case seminar: a novel LHX3 mutation presenting as combined pituitary hormonal deficiency. $\mathbf{J}$ Clin Endocrinol Metab 2006;91(3):747-53. 
14. Sloop KW, Parker GE, Hanna KR, Wright HA, Rhodes SJ. LHX3 transcription factor mutations associated with combined pituitary hormone deficiency impair the activation of pituitary target genes. Gene 2001;265(1-2):61-9.

15. Machinis K, Pantel J, Netchine I, Léger J, Camand OJ, Sobrier $\mathrm{ML}$, et al. Syndromic short stature in patients with a germline mutation in the LIM homeobox LHX4. Am J Hum Genet 2001;69(5):961-8.

16. Radovick S, Nations M, Du Y, Berg LA, Weintraub BD, Wondisford FE. A mutation in the POU-homeodomain of Pit-1 responsible for combined pituitary hormone deficiency. Science 1992;257(5073):1115-8.

17. Wu W, Cogan JD, Pfäffle RW, Dasen JS, Frisch H, O'Connell $\mathrm{SM}$, et al. Mutations in PROP1 cause familial combined pituitary hormone deficiency. Nat Genet 1998;18(2):147-9.

18. Pernasetti F, Toledo SP, Vasilyev VV, Hayashida CY, Cogan JD, Ferrari C, et al. Impaired adrenocorticotropin-adrenal axis in combined pituitary hormone deficiency caused by a twobase pair deletion (301-302delAG) in the prophet of Pit-1 gene. J Clin Endocrinol Metab 2000;85(1):390-7.

19. Deladoëy J, Flück $C$, Büyükgebiz $A$, Kuhlmann BV, Eblé $A$, Hindmarsh PC, et al. "Hot spot" in the PROP1 gene responsible for combined pituitary hormone deficiency. J Clin Endocrinol Metab 1999;84(5):1645-50.

20. Fofanova O, Takamura N, Kinoshita E, Vorontsov A, Vladimirova V, Dedov I, et al. MR imaging of the pituitary gland in children and young adults with congenital combined pituitary hormone deficiency associated with PROP1 mutations. AJR Am J Roentgenol 2000;174(2):555-9.

21. Sobrier ML, Maghnie M, Vié-Luton MP, Secco A, di lorgi N, Lorini R, et al. Novel HESX1 mutations associated with a lifethreatening neonatal phenotype, pituitary aplasia, but normally located posterior pituitary and no optic nerve abnormalities. J Clin Endocrinol Metab 2006;91(11):4528-36.

22. Tajima T, Hattorri T, Nakajima T, Okuhara K, Sato K, Abe S, et al. Sporadic heterozygous frameshift mutation of HESX 1 causing pituitary and optic nerve hypoplasia and combined pituitary hormone deficiency in a Japanese patient. J Clin Endocrinol Metab 2003;88(1):45-50.

23. Mendonça BB, Osorio MG, Latrônico AC, Estefan V, Lo LS, Arnhold IJ. Longitudinal hormonal and pituitary imaging changes in two females with combined pituitary hormone deficiency due to deletion of A301,G302 in the PROP1 gene. $\mathbf{J}$ Clin Endocrinol Metab 1999;84(3):942-5

24. Riepe FG, Partsch CJ, Blankenstein O, Monig H, Pfaffle RW, Sippell WG. Longitudinal imaging reveals pituitary enlargement preceding hypoplasia in two brothers with combined pituitary hormone deficiency attributable to PROP1 mutation. J Clin Endocrinol Metab 2001;86(9):4353-7.

25. Vallette-Kasic S, Barlier A, Teinturier C, Diaz A, Manavela M, Berthezène $F$, et al. PROP1 gene screening in patients with multiple pituitary hormone deficiency reveals two sites of hypermutability and a high incidence of corticotroph deficiency. J Clin Endocrinol Metab 2001:86(9):4529-35.

26. Voutetakis A, Argyropoulou M, Sertedaki A, Livadas S, Xekouki $\mathrm{P}$, Maniati-Christidi $\mathrm{M}$, et al. Pituitary magnetic resonance imaging in 15 patients with PROP1 gene mutations: pituitary enlargement may originate from the intermediate lobe. J Clin Endocrinol Metab 2004;89(5):2200-6.

27. Teinturier $C$, Vallette $S$, Adamsbaum $C$, Bendaoud $M$, Brue $T$, Bougneres PF. Pseudotumor of the pituitary due to PROP-1 deletion. J Pediatr Endocrinol Metab 2002;15(1):95-101.

28. Nascif SO, Vieira TC, Ramos-Dias JC, Lengyel AM, Abucham $\mathrm{J}$. Waxing and waning of a pituitary mass in a young woman with combined pituitary hormone deficiency (CPHD) due to a PROP-1 mutation. Pituitary 2006;9(1):47-52.

29. Argyropoulou M, Perignon F, Brunelle F, Brauner R, Rappaport R. Height of normal pituitary gland as a function of age evaluated by magnetic resonance imaging in children. Pediatr Radiol 1991;21(4):247-9.

30. Tsunoda A, Okuda O, Sato K. MR height of the pituitary gland as a function of age and sex: especially physiological hypertrophy in adolescence and in climacterium. AJNR Am J Neuroradiol 1997;18(3):551-4.
31. Ohta K, Nobukuni $Y$, Mitsubuchi $H$, Fujimoto $S$, Matsuo $N$, Inagaki $\mathrm{H}$, et al. Mutations in the Pit-1 gene in children with combined pituitary hormone deficiency. Biochem Biophys Res Commun 1992;189(2):851-5.

32. Vieira TC, Dias da Silva MR, Cerutti JM, Brunner E, Borges M, Arnaldi LT, et al. Familial combined pituitary hormone deficiency due to a novel mutation R99Q in the hot spot region of Prophet of Pit-1 presenting as constitutional growth delay. $\mathbf{J}$ Clin Endocrinol Metab 2003;88(1):38-44.

33. Reynaud R, Gueydan M, Saveanu A, Vallette-Kasic S, Enjalbert $A$, Brue T, et al. Genetic screening of combined pituitary hormone deficiency: experience in 195 patients. J Clin Endocrinol Metab 2006;91(9):3329-36.

34. Osorio MG, Marui S, Jorge AA, Latronico AC, Lo LS, Leite CC, et al. Pituitary magnetic resonance imaging and function in patients with growth hormone deficiency with and without mutations in GHRH-R, GH-1, or PROP-1 genes. J Clin Endocrinol Metab 2002;87(11):5076-84.

35. Arslanoglu I, Kutlu H, Isguven P, Tokus F, Isik K. Diagnostic value of pituitary MRI in differentiation of children with normal growth hormone secretion, isolated growth hormone deficiency and multiple pituitary hormone deficiency. J Pediatr Endocrinol Metab 2001;14(5):517-23.

36. el Gammal T, Brooks BS, Hoffman WH. MR imaging of the ectopic bright signal of posterior pituitary regeneration. AJNR Am J Neuroradiol 1989;10(2):323-8.

37. Turton JP, Mehta A, Raza J, Woods KS, Tiulpakov A, Cassar J, et al. Mutations within the transcription factor PROP1 are rare in a cohort of patients with sporadic combined pituitary hormone deficiency (CPHD). Clin Endocrinol (Oxf) 2005:63(1):10-8.

38. Fofanova O, Takamura N, Kinoshita E, Parks JS, Brown MR, Peterkova VA, et al. Compound heterozygous deletion of the PROP-1 gene in children with combined pituitary hormone deficiency. J Clin Endocrinol Metab 1998;83(7):2601-4.

39. Asteria C, Oliveira JH, Abucham J, Beck-Peccoz P. Central hypocortisolism as part of combined pituitary hormone deficiency due to mutations of PROP-1 gene. Eur J Endocrinol 2000;143(3):347-52.

40. Agarwal G, Bhatia V, Cook S, Thomas PQ. Adrenocorticotropin deficiency in combined pituitary hormone deficiency patients homozygous for a novel PROP1 deletion. J Clin Endocrinol Metab 2000;85(12):4556-61.

41. Arroyo A, Pernasetti F, Vasilyev VV, Amato P, Yen SS, Mellon $\mathrm{PL}$. A unique case of combined pituitary hormone deficiency caused by a PROP1 gene mutation (R120C) associated with normal height and absent puberty. Clin Endocrinol (Oxf) 2002:57(2):283-91.

42. Lazar L, Gat-Yablonski G, Kornreich L, Pertzelan A, Phillip M. $P R O P-1$ gene mutation (R120C) causing combined pituitary hormone deficiencies with variable clinical course in eight siblings of one Jewish Moroccan family. Horm Res 2003;60(5):227-31.

43. Lemos MC, Gomes L, Bastos M, Leite V, Limbert E, Carvalho $\mathrm{D}$, et al. PROP1 gene analysis in Portuguese patients with combined pituitary hormone deficiency. Clin Endocrinol (Oxf) 2006;65(4):479-85.

44. Laumonnier F, Ronce N, Hamel BC, Thomas P, Lespinasse J, Raynaud M, et al. Transcription factor SOX3 is involved in Xlinked mental retardation with growth hormone deficiency. Am J Hum Genet 2002;71(6):1450-5.

45. Woods KS, Cundall M, Turton J, Rizotti K, Mehta A, Palmer R, et al. Over- and underdosage of SOX3 is associated with infundibular hypoplasia and hypopituitarism. Am J Hum Genet 2005;76(5):833-49.

Endereço para correspondência:

Teresa C. Vieira

Division of Endocrinology, Department of Medicine

Escola Paulista de Medicina, Universidade Federal de São

Paulo

Rua Pedro de Toledo 910

04039-002 São Paulo, SP

Fax: (1 1 ) 3022-6227

E-mail: teresavieira-endo@pesquisa.epm.br 